\title{
ANTIGEN CHARACTERIZATION OF VECTOR-BORNE AND CULTURED METACYCLIC TRYPOMASTIGOTES OF TRYPANOSOMA CRUZI
}

\author{
N. YOSHIDA, M. M. G. TERXEmA \& C. A. SBRAVATE
}

\section{S U M M A Y Y}

Metacyclic trypomastigotes of the CL strain of Trypanosoma cruzi obtained from triatomid vectors and from axenic cultures were comparatively analysed as to their antigen make-up and immunogenic characteristics. They were found to be similar by the various parameters examined. Thus, sera of mice immunized with either one of the two metacyclic types precipitated a $82 K d$ surface protein from ${ }^{131}$ I-labeled culture metacyclics. Sera of mice protected against acute $\mathbf{T}$. cruzi infection by immunization with killed culture metacyclics of a different strain (G) recognized, by immunoblotting, a $77 \mathrm{Kd}$ protein in both types of CL strain metacyclics. A monoclonal antibody raised against $G$ strain metacyclics, and specific for metacyclic stages of this strain, reacted with both CL strain metacyclic types. Both metacyclic forms were similarly lysed by various anti-T. cruzi sera, in a complement-mediated reaction.

KEY-WORDS: Chagas'disease - vector borne - Trypanosoma cruzi, cultured metacyclic tripomastigotes.

\section{N T ROD U C T I O N}

Natural infection by Trypanosoma cruzi, the protozoan parasite that causes Chagas' disease, is initiated when metacyclic trypomastigotes contained in the feces of triatomid vectors enter the vertebrate host. Of the various developmental stages of $\mathbf{T}$. cruzi, trypomastigotes derived from insect vectors are the most. poorly studied. Until recently, when the vectorborne metacyclics were shown to have antigens common to all the developmental forms of $T$. cruzi (VILLALTA \& KIERSZENBAUM ${ }^{15}$ ) or to be susceptible to antibody-dependent, complement-mediated, destruction in vitro (KIERSZENBAUM \& LIMA ${ }^{6}$ ), one of the few informations available on this insect stages was their high infective capacity. This scarcity of data on the insect trypomastigotes is greatly due to the difficulties in obtaing appreciable numbers of these forms from triatomid feces. Since me- tacyclics can be easily obtained in axenic cultures, these trypomastigotes have been generally used as equivalents of their insect counterparts (NOGUEIRA et al. 12). However, up to the present, the actual similarities between metacyclic trypomastigotes from different origins have not been demonstrated.

In this study we attempted to determine whether metacyclic trypomastigotes from triatomids and from culture media are immunologically equivalent. For that purpose both types of metacyclics of the CL strain were examined as to their immunogenicity, antigen make-up and susceptibility to complement-mediated $\mathrm{im}$. munolysis.

\section{MATERIAL AND METHODS}

The CL strain of $T$. cruzi, isolated from Triatoma infestans (BRENER \& CHIARI 1), 
YOSHIDA, N; TEIXEIRA, M. M. G. \& SBRAVATE, C. A. - Antigen characterization of vector-borne and cultured metacyclic trypomastigotes of Trypanosoma cruzt. Rev. Inst. Med. trop. São Paulo, 28:80-86 1986.

was used for antigen characterization. This strain has been maintained cyclically in mice and in either the insect vector $\mathbf{T}$. infestans or liver infusion tryptose (LIT) medium (CAMAR$\mathrm{GO}$ 2). To immunize mice, in addition to the $\mathrm{CL}$ strain, we used the $G$ strain, isolated from an opossum by Mena Barreto (YOSHIDA ${ }^{17}$ ).

Cultured metacyclics were purified through passage in DEAE-cellulose column, as previously described (YOSHIDA ${ }^{17}$ ). Insect-derived trypomastigotes were prepared as follows: T. infestans infected with $T$. cruzi were fed on mice and soon after the blood meal most insects eliminated clear transparent drops of liquid (urine) that were individually examined under phase contrast microscope to verify the presence of parasites. Samples containing trypomastigotes, either uncontaminated or mixed with a small number of epimastigotes, were pooled so that the final preparation contained more than $95 \%$ metacyclics. Urine from equivalent numbers of non-infected T. infestans was also collected to serve as controls.

Outbred albino male mice were immunized with metacyclic trypomastigotes inactivated by heating at $50^{\circ} \mathrm{C}$ for $10 \mathrm{~min}$. All animals received 6 weekly doses by the intraperitoneal route. One group of mice received $5 \times 10^{4}$ killed $\mathrm{CL}$ strain metacyclics derived from $T$. infestans. Simultaneously another group of mice was immunized with $5 \times 10^{4}$ culture-derived trypomastigotes of the same strain. A third group of mice was immunized with $5 \times 10^{6}$ inactivated G strain metacyclics purified from LIT medium. Immunized mice were bled from the retro-orbital plexus one week after the last immunizing dose. Mice infected with the CL strain also served as source of immune sera. Sera from infected mice were collected 4 weeks and 7 weeks after inoculation of T. cruzi. All antisera were aliquoted and stored at-20 ${ }^{\circ} \mathrm{C}$ until used.

To produce hybridoma, Balb/c mice were immunized intravenously with 3 doses of $10^{7}$ heat-inactivated metacyclic trypomastigotes of T. cruzi G strain purified from LIT medium. Four days after the last immunizing dose, when anti.T. cruzi antibodies were detected in the serum of immunized mice, spleen cells from a mouse were recovered and fused with P3U1 plasmacytoma cells (KOHLER \& MILSTEIN ?, POTOCNJAK et al. ${ }^{13)}$. The hybridoma supernatants were screened by indirect immunofluo- rescence (IF) test using formaldehyde-fixed $G$ strain metacyclic trypomastigotes as antigens.

For lysis assay, metacyclic trypomastigotes of the CL strain were incubated at room temperature for $15 \mathrm{~min}$ with $50 \mu \mathrm{l}$ of either normal or immune mouse serum previously heated at $56^{\circ} \mathrm{C}$ for $30 \mathrm{~min}$. Thereafter $50 \mu 1$ of normal serum was added as source of complement and the parasites were incubated at $37^{\circ} \mathrm{C}$ for 1 hour. To determine the percentage of trypomastigote lysis, samples were examined under phase contrast microscope and the number of motile intact metacyclics were counted against the number of lysed parasites.

Trypomastigotes were labeled with 131 I by the Iodo-Gen method (MARKWELL \& FOX 11) as described by CAMARGO et al. ${ }^{3}$. Preparation of parasite extract, immunoprecipitation by KESSLER's method ${ }^{5}$, sodium dodecyl sulphate polyacrylamide gel electrophoresis (LAEMMLI ${ }^{10)}$ using $7 \%$ slab gels, and radioautography were performed as already described (YOSHIDA ${ }^{17}$, YOSHIDA et al. ${ }^{18}$ ).

For metacyclic antigen determination we also used Western blot analysis ,TOWBIN et al. ${ }^{14)}$. Live parasites were placed in reducing buffer containing $2 \%$ SDS, $10 \%$ glycerol, $10 \%$ $\beta$-mercaptoethanol and 6M urea in the presence of protease inhibitors. The extracts were subjected to SDS-PAGE, using $7 \%$ slab gels for separation and $\mathbf{5 \%}$ gels for stacking, and then electroblotted overnight at $4^{\circ} \mathrm{C}$ to a nitrocellulose membrane. The membrane was incubated at room temperature with phosphate buffered saline (PBS) containing 5\% defatted milk and then incubated for $1 \mathrm{hr}$ with anti-T.cruzi mouse serum at a final dilution of $1: 50$ in PBS-milk. Negative controls were incubated under the same conditions with normal mouse serum. All preparations were washed 3 times with PBS containing $1 \%$ milk and thereafter incubated for $1 \mathrm{hr}$ with affinity-purified goat antimouse 125T-labeled immunoglobulin $\left(10^{6} \mathrm{cpm} / \mathrm{ml}\right)$. After 4 washings with PBS containing $0.05 \%$ Tween 20 , the membrane was dried and exposed to an $\mathrm{X}$-ray film at $-70^{\circ} \mathrm{C}$.

\section{RESULTS}

Sera of mice immunized with inactivated CL strain metacyclics, derived from either triatomids of LIT medium, immunoprecipitated a 
YOSHIDA, N:; TEIXEIRA, M. M. G. \& SBRAVATE, C. A. - Antigen characterisation of vector-borne and cultured metacyclic trypomastigotes of Trypanosoma eruzl. Rev. Inst. Med. trop. Sio Paulo, 28:80-86 1986.

major 82Kd surface protein upon reaction with 131 I-labeled culture CL strain trypomastigote extracts (Fig. 1, lanes a and b). We were not able to determine the insect-derived metacyclic an. cigens, in spite of repeated attempts, due to smaal number of parasites obtained from $T$. infestans, on the order of $10^{5}$, i.e., about 100 ti. mes lower than the number of culture metacyclics used for labeling.

The antigen make-up of CL strain metacyclics from $\mathbf{T}$. infestans and from LIT medium was compared by immunoblotting technique, using sera of mice immunized with killed G strain culture metacyclics. This anti-G serum was selected among others because it reacted with polypeptides of CL strain culture metacyclics, with apparent molecular weights between $70 \mathrm{Kd}$ and $100 \mathrm{Kd}$, (Fig. 1, lane c), previously shown to be the main surface antigens of CL strain culture trypomastigotes (YOSHIDA ${ }^{16}$ ). As shown in Fig. 2 (lanes a and b) a band of $77 \mathrm{Kd}$ was detected in both culture and vectorborne CL strain metacyclics. The fact that only one of the metacyclic antigens is identified by immunoblotting procedure may be due to the small number of parasites used $\left(10^{6}\right)$. Another possibility is that the $77 \mathrm{Kd}$ protein is more efficiently transferred to the nitrocellulose membrane and, therefore, more easily detected.

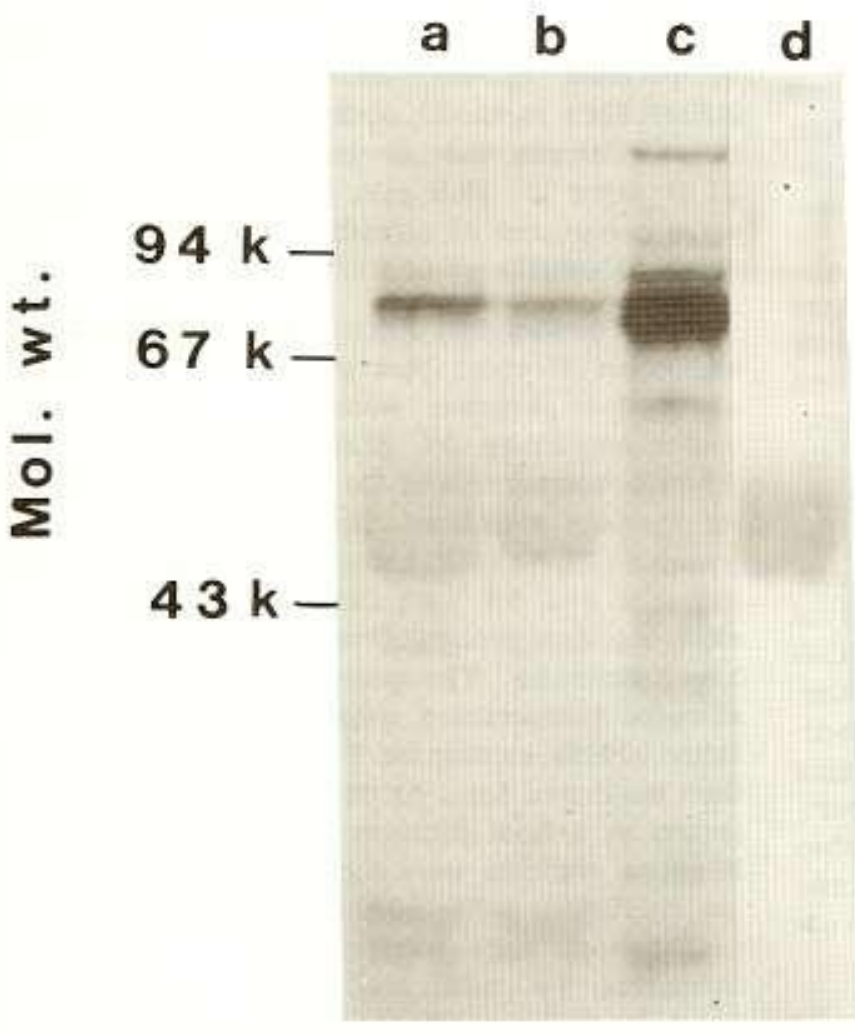

Fig. 1 - Surface antigens of metacyclic trypo. mastigotes of $T$. eruzi $\mathrm{CL}$ strain purifled from LIT medium. 13I-labeled parasite extracts were immunoprecipitated with: sera of mice immunt. zed with hest-inactivated CL strain metacyclics derived from $\mathbf{T}$. intestans (lane a) or purified from culture medium (lane b) : sera of mice Immunized with heat-killed $G$ strain metacyclics (lane o). Precipitation patterns with normal mouse serum sre shown in lane d.

Both insect-derived and cultured CL strain trypomastigotes were found by IF test to react with a monoclonal antibody that did not recognize epimastigotes or blood trypomastigotes. This monoclonal antibody immunoprecipitated a surface protein with an apparent molecular weight of $90 \mathrm{Kd}$ from ${ }^{131}$ I-labeled extracts of CL strain metacyclics purified from LIT medium (Fig. 3, lane a). The presence of this 90Kd an- tigen could not be determined in the insect-bor ne metacyclics due to the already mentioned if mitations.

The CL strain metacyclic trypomastigotes from different origins displayed similar suscep. tibility to complement-mediated immunolysis in vitro (Fig. 4). They were both extensively $1 y$ sed by sera of mice immunized with killed G strain metacyclics as well as by sera of chroni- 


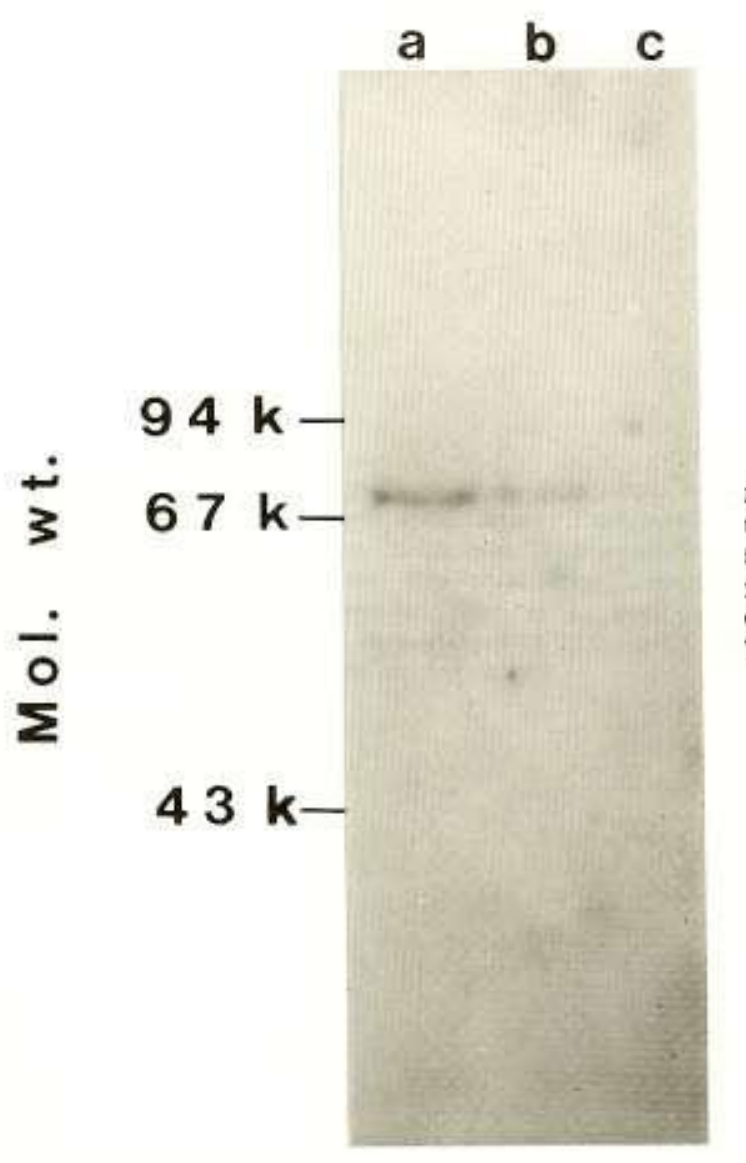

cally infected mice ( 7 week-old infection). Sera of acutely infected mice (4 week old infection) showed low lytic activity while the monoclonal antibody reacting with both metacyclic forms had no trypanolytic effect.

\section{DISCUSSION}

The present findings indicate that metacyclic trypomastigote stage of $\mathbf{T}$. cruzi, derived from triatomid vectors and from culture me. dia, are immunogenically and antigenically si. milar. Thus, sera of mice immunized with either one of the two CL strain metacyclic forms precipitated from ${ }^{13}$ I-labeled culture metacyclics of the CL strain a surface protein of $82 \mathrm{Kd}$. On the other hand, a $77 \mathrm{Kd}$ polypeptide was detected in both metacyclic trypomastigo. tes by the immunoblot technique using sera of mice immunized with killed G strain metacyclics.
Fig. 2 - Western immunblot analysis of extracts of $10^{4}$ metacyclic trypornastigoted of $\mathbf{T}$. cruzi CL strain. Sers of mice immuniaed with heat-Jilled $\mathrm{C}$ strain metacyclics identified a protein with ath apparent molecular weigth of $77 \mathrm{Kd}$ in both culture (lane a) and triatomid (lane b) derived motacyclics. This polypeptide was pot detected in the preparation obtained from non-infected $T$. infestaus (lane $c$ ).

Our results also show that the metacyclic trypomastigotes harvested from distinct milieu have specific antigens not shared by other developmental stages of $\mathbf{T}$. cruxi. A monoclonal antibody that failed to recognize epimastigotes or blood trypomastigotes reacted with both insect and culture metacyclics of the CL strain. A $90 \mathrm{Kd}$ polypeptide was detected by this monoclonal antibody on the surface of culture metacyclics.

Complement-mediated trypanolytic activit of immune sera in vitro has been associated with the presence of protective antibodies (KRETTLI \& BRENER 9 ). Of relevance is, therefore, the finding that both insect and culture $\mathrm{CL}$ strain metacyclics were almost completely lysed by sera of mice immunized with killed G strain metacyclics, and previously shown to be resistant to T. cruzi infection (YOSHIDA et al. ${ }^{\text {') }}$, as well as by sera of chronically infected mice. which have been demonstrated to have protective effect (HANSON ${ }^{4}$, KRETTLI \& BRENER ${ }^{\text {}}$ ). 


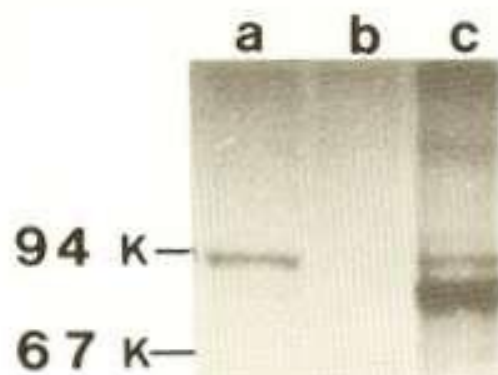

$43 \mathrm{k}-$

We had previously observed that mice immunized with inactivated $\mathrm{G}$ strain metacyclics, but not those immunized with epimastigotes, are resistant to acute $\mathbf{T}$. cruzi infection when challenged with vector-borne CL strain trypomastigotes (YOSHIDA ${ }^{\text {t5)}}$ ) or with their cultured counterparts, but remain susceptible to acute infection by blood trypomastigotes (unpublished observations). Sera of immunized and protected mice reacted with a set of surface antigens of CL strain culture metacyelics, with apparent molecular weights between $70 \mathrm{Kd}$ and $100 \mathrm{Kd}$, which were found to be specific of these developmental stages (YOSHIDA 16). These data, taken together with the present results, reinforce our view that surface proteins, specific of metacyclic forms, but not strain specific, are involved in inducing protective immunity against homologous $\mathbf{T}$. cruzi infective stages.

\section{RESUMO}

\section{Caracterizaçẫo antigêniea de tripomastigotas}

Fir. 3 - SDS-PAGE snalysis of immunoprecipitates of ari-laboled metacyclic trypomastigotes of $\mathbf{T}$. crux $\mathrm{Ct}$ atrain purified from calture with a monoclonal nntibody. Labeled parasite extracts were precipitated with an anti-T. eruxi monoclonal antibody (lane: s) or with the supernatant from P3UI cell culture (lane b). The pattern of the total parasite extract in shown in tane $c$. metaciclicos de Trypanosoma cruzi provenientes do vetor e de cultura

Tripomastigotas metacíclicos da cepa CL de Trypanosoma cruzi, originários de triatomíneos e de cultura axênica, foram comparativamente analisados quanto a sua composiçấo antigênica e caracteristicas imunogênicas. Os vários parâmetros examinados mostraram que as duas formas metaciclicas săo semelhantes. Assim, soros de camundongos imunizados com qualquer uma das formas metaciclicas precipitaram uma proteina de superficie de $82 K d$ de tripomastigotas metaciclicos de cultura marcados com 13i. Soros de camundongos protegidos contra infecçăo aguda por T. cruzi, por imunizaçăo com formas metaciclicas de cultura inativadas, de uma cepa diferente (G), detectaram por imunoblotting uma proteina de $77 \mathrm{Kd}$ em ambas as formas metaciclicas da cepa CL. Um anticorpo monoclonal, produzido contra as for mas metaciclicas da cepa $G$, e especifico para 
YOSHIDA, N.; TEIXEIRA, M. M. G. \& SBRAVATE, C. A. - Antigen characterization of vector-borne and cultured me tacyclic trypomastigotes of Trypanosoma cruzl. Rev. Inst. Med. trop. São Paulo, 28:80-86 1986.

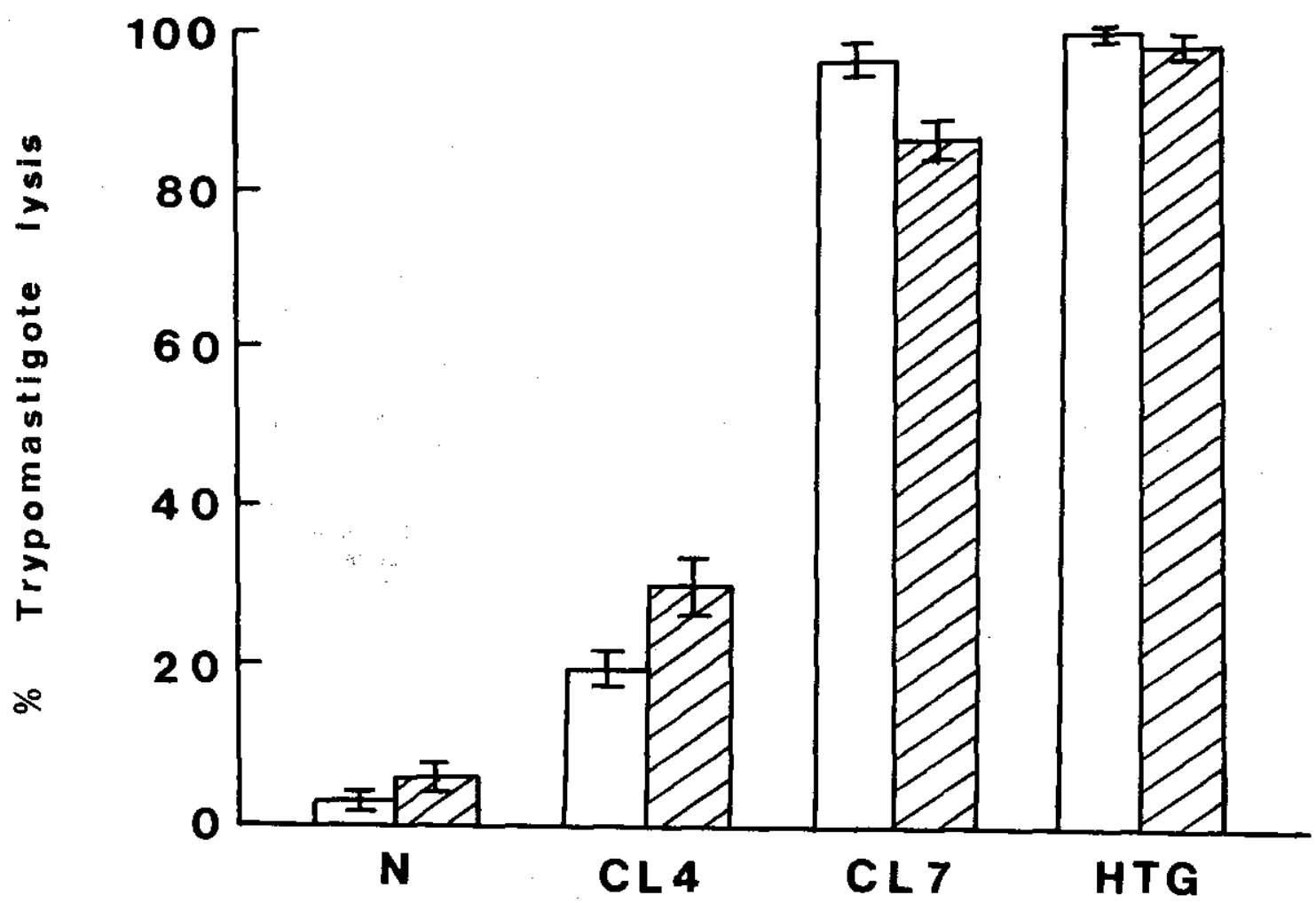

Fig. 4 - Susceptibily it of metacyclic trypomastigotes of T. cruzi CL strain to complement-mediated immunolysis. Metacyclics purifled from LIT medium ( $\square$ ) or obtained from $T$. infestans ( $\square$ ) were incubated with: normal mouse serum $(N)$, sera from mice with 4 week-old (CLA) or 7 week-old (CL7) infection by the CL strain, and sera trom mice immunized with heat-kiilled metacyclics of the $G$ strain (HTG), in the presence of normal human serum as source of complement.

tripomastigotas metacíclicos, reagiu com formas metacíclicas da cepa CL tanto do vetor quanto de cultura. As duas formas metacíclicas mostraram suscetibilidade semelhante à lise por vários soros anti-T. cruzi, em uma reação mediada por complemento.

\section{ACKNOWLEDGEMENT}

This work was supported by Fundação de Amparo à Pesquisa do Estado de São Paulo (FAPESP), Conselho Nacional de Desenvolvimento Científico e Tecnológico (CNPq) and FINEP. Brasil.

We thank Dr. Erney P. Camargo for reviewing the manuscript, Dr. Fidel Zavala for critical reading of the manuscript and Ms. $M$. Russo for excelent technical assistance.

\section{REFERENCES}

1. BRENER, Z. \& CHIARI, E. - Variaçöes morfologicas observadas em diferentes amostras de Trypanosoma cruzi. Rev. Inst. Med. trop. S. Paulo, 5: 220-224, 1963.
2. CAMARGO, E. P. - Growth and differentiation in Trypanosoma cruzi. I. Origin of metacyclic trypanosomes in liquid media. Rev. Inst. Med. trop. S. Paulo, 6: $93-100,1964$.

3. CAMARGo, E. P.; MatTEI, D. M.; BARBIERI, C. L. \& MOREL, C. M. - Electrophoretic analysis of endonuclease-generated fragments of K-DNA, of esterase isoen. zymes and surface proteins as aids for species ident1fication of insect trypanosomatids. J. Protozool., 29: 251-258, 1982.

4. HANSON, W. L, - Immune response and mechanisms of resistance in Trypanosoma cruzi. Pan Amer. Hith. Org. Scient. Publ., 347: 22-34, 1977.

5. KESSLER, S. W. - Rapio isolation of antigens from cells with staphylococcal protein $\mathrm{A}$ antibody absorbent: parameters of the interaction of antibody antigen com. plexes with protein A. J. Immunol., 115: 1617-1624, 1975.

6. KIERSZENBAUM, F. \& LIMA, M. F. - Susceptibility of insectborne, metacyclic forms of Trypanosoma cruzi to antibody-mediated mechanisms of destruction. Amer. J. trop. Med. Hyg., 32: 1236-1241, 1983.

7. KOHLER, G. \& MILSTEIN, C. - Continuous cultures of fused cells secreting antibody of predefined speci. ficity. Nature (London), 256: 495-497, 1975. 
YOSHIDA, N.; TEIXEIRA, M. M. G. \& SBRAVATE, C. A. - Antigen characterization of vector-borne and cultured me. tacyclic trypomastigotes of Trypanosoma cruzi. Rev. Inst. Med. trop. São Paulo, 28:80-86 1986.

8 KRETTLI, A. U. \& BRENER, z. - Protective effects of specific antibodies in Trypanosoma cruzl infection. J. 'Immunol., 116: 755-760, 1976.

9. KRETTLI, A. U. \& BRENER, Z. - Resistance against Trypanosoma cruzi associated to anti-living trypomasti. gote antibodies. J. Immunol., 128: 2009-2012, 1982.

10. LAEMMII, U. $\mathbf{K}$. - Cleavage of structural proteins during the assembly of the head of bacteriophage T4. Nature (London), 227: 680-685, 1970.

11. MARKWELL, M. A. K. \& FOX, C. F. - Surface-specific lodination of membrane proteins of viruses and eukaryotic cellis using $1,3,4,6$-tetrachloro- $3 \alpha, 6 \alpha$-diphenylglycoluril. Biochemistry, 17: 4807-4817, 1978.

12. NOGUEIRA, N.; UNKELLESS, J. \& COHN, Z. - Spe. cific glycoprotein antigens on the surface of insect and mammalian stages of Trypanosoma cruzi. Proc. nat. Acad. Sci. (Wash.), 79: 1259-1263, 1982.

13. POTOCNJAK, P.; YOSHIDA, N.; NUSSENZWEIG, R. S. \& NUSSENZWEIG, V. - Monovalent fragments (Fab) of monoclonal antibodies to a sporozoite sur. face antigen $(\mathrm{Pb} 44)$ protect mice against malarlal infection. J. exp. Med., 151: 1504-1513, 1980.

14. TOWBIN, H.; STAEHELIN, T. \& GORDON, J. - Electrophoretic transfer of proteins from polyacrylamide gels to nitrocellulose sheets: Procedures and some applications. Proc. natl. Acad. Scl. (Wash.), 76: 4350 4354,1979 .

15. VILLALTA, F. \& KIERSZENBAUM, F. - Cross-reactivity of vectorborne metacyclic forms of Trypanosoma cruzi with mammalian and culture stages. J. Protozool., 30: $329 \cdot 331,1983$.

16. YOSHIDA, N. - Trypanosoma cruzi: Recognition of trypomastigote surface antigens by lytic antisera from mice resistant to acute infection. Exp. Parasit. (In press).

17. YOSHIDA, N. - Surface antigens of metacyclic try. pomastigotes of Trypanosoma cruzi. Infect Immun. 40: 836-839, 1983.

18. YOSHIDA, N.; POTOCNJAK, P.; NUSSENZWEIG, V. \& NUSSENZWEIG, R. S. - Biosynthesis of Pb44, the protective antigen of sporozoites of Plasmodium ber. ghei. J. exp. Med., 154: 1225-1236, 1981.

19. YOSHIDA, N.; TEIXEIRA, M. M. G.; CHRISTO, C B. \& SBRAVATE, C. A. - Resistance of mice immu. nized with killed culture trypomastigotes against in. fection by insect-derived trypomastigotes of Trypano soma cruzl. Rev. Inst. Med. trop. S. Paulo, 26: 329. 333 , 1984 .

Recebido para publicação em $8 / 4 / 1985$. 